\title{
, \\ Digitalization of Work and Human Resources Processes as a Way to Create a Sustainable and Ethical Organization
}

\author{
Aleksandra Kuzior ${ }^{1}\left[\right.$, Karolina Kettler ${ }^{1, *}$ and Łukasz Rąb ${ }^{2, *} \mathbb{C}$ \\ 1 Department of Applied Social Sciences, Faculty of Organization and Management, Silesian University of \\ Technology, 26-28 Roosevelt St., 41-800 Zabrze, Poland; aleksandra.kuzior@polsl.pl \\ 2 Department of Philosophy of Morality and Global Ethics, Maria Grzegorzewska University, \\ 02-353 Warsaw, Poland \\ * Correspondence: karolina.alina.kettler@gmail.com (K.K.); lrab@aps.edu.pl (Ł.R.)
}

check for updates

Citation: Kuzior, A.; Kettler, K.; Rąb, Ł. Digitalization of Work and Human Resources Processes as a Way to Create a Sustainable and Ethical Organization. Energies 2022, 15, 172. https://doi.org/10.3390/en15010172 Academic Editors: David Borge-Diez and Luigi Aldieri

Received: 13 November 2021 Accepted: 22 December 2021 Published: 28 December 2021

Publisher's Note: MDPI stays neutral with regard to jurisdictional claims in published maps and institutional affiliations.

Copyright: (C) 2021 by the authors. Licensee MDPI, Basel, Switzerland. This article is an open access article distributed under the terms and conditions of the Creative Commons Attribution (CC BY) license (https:// creativecommons.org/licenses/by/ $4.0 /)$.

\begin{abstract}
Remote and hybrid working models and accelerated digitalization of the human resources processes were introduced in most organizations worldwide as a consequence of the COVD-19 pandemic. This digital revolution at the workplace was forced by extraordinary circumstances, thus its impact had not been anticipated before. This motivated the authors to study the new work reality. The research was based on a hypothesis that the digitalization of work and the human resources processes, approaches organizations to the sustainable development ideal. Sustainability is here understood as maintaining a balance between economic, environmental, and social factors. The authors analyzed the impact between the digital processes and the way of working on the following areas: $\mathrm{CO}_{2}$ emissions, creating plastic waste, saving energy, creating a gender-diverse and inclusive workplace. To verify the hypothesis, the authors used their own original and desk research. The original research was conducted within a Berlin-based tech startup between March 2020 and August 2021. Additionally, the authors ran surveys among international startups and scale-ups. Based on their findings the authors concluded that there can be a positive correlation between digitalization and increased organizational sustainability. This result is significant not only for the human resources specialists but can indicate a direction for a general business strategy.
\end{abstract}

Keywords: sustainable development; humanistic management; sustainable organization; surveillance capitalism; pandemic; remote work; environmental protection; carbon footprint; diversity and inclusion; remote work; philosophy of digital life

\section{Introduction}

The outbreak of the coronavirus has deeply impacted the way people work. The accelerated digitalization of processes and working models did not happen for many organizations as a result of long-term planning but was rather imposed by lockdowns and external restrictions. In the authors' opinion, this currently happening work $\mathrm{r}(\mathrm{e})$ volution could be either a major opportunity or a threat for the labor world. We could on the one hand expect that thanks to remote work and digitalized processes, the workers would be freed from the bonds of time, location, and social circumstances restrictions. On the other hand, this digital change brings as well advanced monitoring possibilities, which could turn the post-pandemic workplaces into panopticons, places, where workers are constantly controlled and deprived of freedom.

Organizations following the first path become more sustainable [1]. Sustainability is here understood as maintaining a balance between economic, environmental, and social factors. If employees are not restricted by location, time, and social circumstances, this influences not only their lives but contributes to a wider social and environmental change. According to the authors, the practical application of sustainable development within organizations is humanistic management. Humanistic management can be described as a trend 
that places people and their natural and social environment at the center. As underlined by Kostera, one of the most important Polish propagators of humanistic management, building a sustainable, humanistically managed organization, means putting emphasis on creating a positive impact on individuals, groups, and the environment [2]. Classical management does not stand, or at least should not, in contradiction with humanistic management. What we are talking here about is the restoration of the main role in the organization of an employee. Thinking in economic terms is important not only from the point of view of the generated profit but also for achieving goals of the general social dimension (such as providing jobs [2]. This is an obvious reference to Adam Smith, who in the "theory of moral feelings" postulates the use of reason not only for getting rich but above all for respecting moral principles [3].

Improving the conditions and atmosphere at work was the subject of considerations already in the 1930s (E. Mayo's school of interpersonal relations), but it was not until the end of the 20th century that an approach that puts people in the foreground developed [4]. The last two decades have brought an increase in the number of scientific studies on humanistic management, which primarily emphasize the value of man, respect for individual dignity, and improvement of the quality of life. This will be the subject of the author's further research [5]. Therefore, it should be underlined once again that these postulates of humanistic management are consistent with the assumptions of sustainable development and the functioning of a sustainable organization [6]. Humanistic management is understood in the context of new challenges related to environmental protection and the rational use of shrinking resources through solutions based on the circular economy [7]. Extending these issues with the human aspect is clearly reflected in the idea of CSR (Corporate Social Responsibility) [8], and more effective implementation of sustainable development goals [9]. However, despite the increased interest in humanistic management, no satisfactory formula for the implementation of theoretical solutions into management practice has been developed yet.

Both theorists and management practitioners have long understood that the good functioning of an organization is largely based on properly implemented human resources processes, ranging from recruitment processes to human resource management. The literature on the subject is extensive [10-16]. The Scopus database for the Human Resources Management query finds 176,294 document results in keywords, titles and abstracts. The Publons database finds 1,374,926 results after publication titles containing the phrase "Human Resources Management". Human resource management also appears in a new "green" approach (Green HRM) [17]. On the other hand, for the query "human resources processes", Publons finds 1,020,156 results, and Scopus 92.390 document results. There are relatively few studies on HR processes and human resource management in the digitization era [18-22].

Taking the above into consideration and with the intention to fill the research gap, the authors analyzed the aspects of human resources processes (recruitment) and new working models (remote and hybrid) in light of the sustainable development and humanistic management basic assumptions (see above). The hypothesis being verified was as follows: The corona-caused digitalization of work and human resources processes helps organizations in achieving the ideal of sustainability. Being able to test this hypothesis is important not only from the human resources management perspective but as well from the wider business strategy standpoint. Currently, the digital shift has been imposed by external circumstances. However, if organizations and their leaders understand better the mechanisms behind this change, it will help them build more aware, long-term strategies that could contribute positively to social and environmental change.

\section{Materials and Methods}

The authors decided to use a case study research design. The aim was to conduct an in-depth study of the topic of the digitalization processes caused by the current pandemic and their influence on organizational sustainability. 
A case study research design is particularly useful when the subject in question is not yet well described or researched. However, the authors treat their initial research as an introduction to a further broader research project.

The objective of the authors' study was to verify the following hypothesis: The corona-caused digitalization of work and human resources processes helps organizations in achieving the ideal of sustainability. The authors decided to choose this research hypothesis for the following reasons:

- $\quad$ Research gap: (1) the topic of accelerated digitalization during the current pandemic and its influence on sustainability is relatively poorly described (2) the number of scientific articles on startups is low [23].

- Scientific significance: the research will provide a new perspective on organizational sustainability and may lead to new in-depth research on the topic of digitalization and its correlation with sustainable development.

- Practical application: for business leaders and human resources specialists, a deeper understanding of the interconnection between digitalization and sustainability will (may lead) lead to building long-term strategies aligned with the ideals of humanistic management and sustainable development.

The stated hypothesis was being verified by the authors through the following research methods:

- $\quad$ Primary source data collection (surveys, in-depth interviews).

- Secondary research data collection.

The original study was conducted in the time frame between March 2020 and August 2021 within a Berlin-based tech startup. At the beginning of the study, the company consisted of 55 employees and grew by August 2021 up to 72 workers. All of the employees consist of so-called white-collar workers-100\% hold a university diploma or equivalent.

Each quarter engagement surveys (seven rounds) were distributed among the employees via an internal online tool. In total, 375 surveys were sent to the employees during the study time period. On average, the response rate (returned, completed surveys) was at the $90 \%$ level. The same tool for distribution was also used to collect and analyze the data.

To obtain a more in-depth perspective, the authors conducted face-to-face in-depth interviews with the line managers (one interview per every two quarters, three rounds, in total 34 individual in-depth interviews). The data was manually registered in the online tool and then analyzed with the same software as the engagement surveys.

Additionally, the authors ran two surveys within Berlin startups and scaleups, whose human resources specialists and managers belong to the Secret HR Society-an international organization for human resources and recruitment professionals. The data from these surveys were collected and analyzed via an external online survey tool. In total, 20 surveys were completed and returned.

\section{Remote Work and Remote Recruitment}

Before the beginning of the COVID-19 pandemic, the remote or hybrid working model had been more of a rare perk than day-to-day reality. However, since March 2020, most of the companies worldwide have shifted, there, where it was possible, into a home office way of working. After a year and a half with the pandemic restrictions, this digital work has become a new normal, which, according to several studies, will stay with us for good.

Based on a survey conducted by CNBC among the top US companies, most of them will remain in a hybrid and/or remote setup (45\% hybrid, 23\% fully remote) after the restrictions are lifted [24]. In Poland, as the Colliers report shows (study ran among 200 companies in the biggest Polish cities), after the pandemic is over, $77 \%$ of the respondents will continue working in a hybrid model [25]. As for the German enterprises, following the BCG study, $68 \%$ of them will turn into hybrid ones after all the restrictions are lifted [26]. In Berlin, which is dominated by tech startups, this number tends to be even higher. According to a survey run by the authors within 20 Berlin startups and scale-ups, all of them are shifting 
into hybrid and/or remote-first companies. 17 out of 20 reviewed organizations will offer a combination of hybrid and fully remote options based on the individual employee choices. As for the examined company, it shifted to a fully remote setup in March 2020. As of today (August 2021) the enterprise offers hybrid and remote options. The fully vaccinated employees, who wish to work from the office, need to sign up beforehand using an app integrated into the internal communication system. There is, however, a limit of 10 people to be present per day. This way of working was chosen by the members of the organization in a company-wide engagement survey.

Recruitment processes had been extensively digitalized already before the pandemic broke out. Most of the talent acquisition specialists had been using digital and/or AIsupported systems in their hiring endeavors. Any organization is currently able to automate a big part of its hiring processes. Currently are used revolutionary recruitment methods based on artificial intelligence solutions, analytics, and human resource, which utilize augmented reality and virtual reality [27-30].

Let us have a closer look at the different stages of attracting a talent that is currently widely used:

- Job descriptions- there are programs that not only help to create and post job descriptions but also use relevant language that is bias-free, gender-neutral, and directed to a concrete target group

- CVs screening - a good ATS (applicant tracking system) can prescreen applications, identify keywords, and place candidates in the right openings

- Scheduling interviews - there are various tools, which can integrate with an online calendar and schedule all steps of the process automatically

- First screens-instead of having recruiters conducting a couple of repetitive phone/video screens per day, a company can introduce a chatbot that will easily replace a human interviewer or/and answer the most frequent questions

- Online tests

- Job offer-many companies nowadays use dedicated software to create offers and have them signed electronically

- Pre-onboarding-activities connected to welcoming a newbie can be easily automated.

However, what the pandemic-related lockdown caused, was adding the whole onboarding process to the scope of digitized recruitment. Companies organize initial training, get-to-know the team, software, and equipment usage tutorials, and more, in the online setup. To make the employee experience smoother, digital conferencing solutions have been improving during the pandemic and adding more real-life features. Currently, while using a remote conference solution, one gets to change the rooms, have an office-like setup, and more.

From the 20 surveyed Berlin startups and scaleups, 100\% will keep the remote/hybrid recruitment process. However, 16 will be/are offering onsite interviewing options for the Berlin-based candidates.

The examined organization shifted completely to digital recruitment, and this setup is going to remain even after the pandemic is over. The applicants from remote locations and Berlin go through the same process and candidate experience.

\section{Digital Work and Environmental Aspects}

The pandemic restrictions affected the environment extensively. Let us have a closer look at how working from home in the past year and a half has influenced our impact on nature.

A huge part of the world's population commutes to work with a car. Driving a car has one of the highest impacts on polluting the air. A study run by Sun Microsystems revealed that a daily car commute to and from work is responsible for $98 \%$ of an employee's work-produced carbon footprint. Given the fact that most of the workers start and finish at the almost same time creating huge traffic jams, these cars produce tons of greenhouse gases daily. To be more precise, only in the US- the second country after China to be having 
the most carbon emissions in the world-an average yearly contribution to carbon footprint per person using a car equals 3.2 tons of carbon. Moreover, transportation, in general, is the biggest source of carbon dioxide emissions in the US, and private vehicles constitute $60 \%$ of the emissions [31]. Air quality has improved significantly in India and China [32]. Analyzes have been carried out on the transition to a low carbon/sustainable economy [33,34].

An estimation made by Global Workplace Analytics showed that if all citizens of the US, who could start working from home (study ran before the pandemic) would do so for half of the week, "it would have the greenhouse gas equivalent of taking the entire New York State workforce off the road" [35]. We can compare this assessment with the data gathered at the end of the year 2020. According to the study conducted by INRIX, vehicle traffic was down by ca. 38\% in the US last year [36]. As for the European examples-for instance, in the United Kingdom transport emissions constitute $21 \%$ of the UK's carbon footprint, and before the pandemic, employees would spend 4.6 million hours on their commute to and from work [37]. Germany, where the usage of cars is one of the highest in Europe and the carbon footprint caused by cars is the highest in the European Union, has seen a drop of the $\mathrm{CO}_{2}$ cars' emissions due to pandemic's lockdown by $8.7 \%$, according to the Federal Environment Agency. However, it is estimated that if the companies were to get back to the full onsite presence model, it would mean an increase of carbon footprint by $6 \%$ in a very short time only due to a daily commute [38]. To summarize, on the global level, according to the report published by the International Energy Agency, 2020 was marked by the largest annual decline of greenhouse gases emission since World War II, which was 6\% [38].

But the home office is not limited to the reduction of private transportation. Working from home significantly changes our practices and behaviors, which has a huge impact on the environment and sustainability. According to research, employees working from home are more energy-usage conscious and tend to save it to a higher extent than people who are present at the office. This is explained by the lack of financial incentives while saving energy at the workplace [39].

Another environmental aspect, deeply linked to the working from the office practices, are eating habits. Many companies offer food delivery options to their employees. This tendency is very strong in the big, often polluted cities. According to a study that was published in "Nature Human Behavior", the more polluted the city, the more likely office workers will order lunch. To be more precise-the research was based on the lunch choices of 251 office employees for 11 days (working week) in three of the most polluted cities of China-Beijing, Shenyang, and Shijiazhuang. Additionally, entries from an online food delivery platform of 350,000 users were checked. By comparing both datasets with air pollution data during the usual lunch break time, researchers discovered that employees were $43 \%$ more likely to order food delivery when there was a $100 \mu \mathrm{g} \mathrm{m}-3$ increase in particulate matter pollution (PM2.5). By contrast, the general public was $7.2 \%$ more likely to use food delivery services with the same increase in air pollution [40].

Intuitively, however, one may suppose that during the pandemic this trend would reverse and people staying and working at home would start heavily ordering readymade food. However, as research shows, the past lockdown changed eating habits into a more healthy and sustainable manner. According to several international studies, during the pandemic, people started cooking at home more extensively. For instance, research conducted among 2200 American (US) consumers showed that over half of them (55\%) started cooking exclusively at home since the pandemic and that $91 \%$ of that group will keep this habit even after the lockdown is over [41]. In Europe, a cross-sectional online survey among 2680 residents of Denmark, Germany, and Slovenia revealed that people working in the home office increased their cooking and baking activities. For instance, according to this study, $25 \%$ of German consumers are more engaged in cooking at home than before the pandemic, and $21 \%$ more in baking [42]. To summarize, according to the preliminary data gathered still during the pandemic, the home office seems to have a positive impact on the environment. 
How is that reflected in the examined company? As already mentioned, in the past year, during both lockdowns introduced in Germany (March 2020-May 2021), the company has been working fully remotely. Currently, a hybrid model has been introduced, with approximately 3 days of onsite presence.

To verify the carbon footprint of the organization by comparing the full onsite, fully remote, and hybrid models, the authors used an online emissions calculator for businesses developed by Planetly. The tool estimates annual emissions depending on the business model, city, and the number of employees. For the examined company the results are shown below (Figures 1-3):

\section{Forecast annual (tCO2e) $\quad 2,601-1.2 \%$}

\begin{tabular}{lrr} 
Workplace (1) & 389 & $-7.8 \%$ \\
Buildings (1) & 103 & $-5.3 \%$ \\
\hline Commuting & 69 & $-40 \%$ \\
\hline Flights & 198 & $+0 \%$ \\
\hline Remote work (1) & 19 & $+\infty$ \\
\hline Employee households & 2,212 & $+0 \%$
\end{tabular}

Figure 1. Forecast-3 days at the office, accessed on 9 September 2021.

Forecast annual (tCO2e)

$2,633+0 \%$

Workplace

Buildings

Commuting

Flights

Remote work

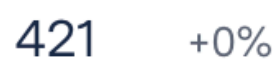

$109+0 \%$

$198+0 \%$

$0+0 \%$

\section{Employee households \\ $2,212+0 \%$}

Figure 2. Forecast -5 days at the office, accessed on 9 September 2021. 
Forecast annual ( $\mathrm{tCO} 2 \mathrm{e})$

\begin{tabular}{lrr} 
Workplace (1) & 245 & $-41.8 \%$ \\
Buildings (1) & 0 & $-100 \%$ \\
Commuting 10 & 0 & $-100 \%$ \\
Flights & 198 & $+0 \%$ \\
\hline Remote work 10 & 47 & $+\infty$ \\
\hline Employee households 10 & 2,212 & $+0 \%$
\end{tabular}

Figure 3. Forecast—fully remote. Source: Planety.com, accessed on 9 September 2021.

As we can see, the fully remote model significantly reduced emissions produced by the enterprise. Moreover, emissions forecasted for the households are always below the ones produced for the company. Taking into account that it is still too early to make a general statement, given the existing data, we can say that remote and hybrid model has a beneficial influence on the environment. On top of this, we should also add the reduction of carbon footprint due to remote recruitment. Before the pandemic, the candidates were flying in from the most remote locations just to attend a couple of hours of interviews. Given that in the examined organization $80 \%$ of the employees relocated to Germany for the job, the reduction in $\mathrm{CO}_{2}$ emissions should be significant (unfortunately, the authors lack a precise calculation of such).

\section{Digitalization and (Gender) Diversity}

The examined company belongs to the tech startup environment. Tech companies, worldwide, are mostly dominated by male employees. Even in the EU countries, this domination is very significant (Figures 4-6):

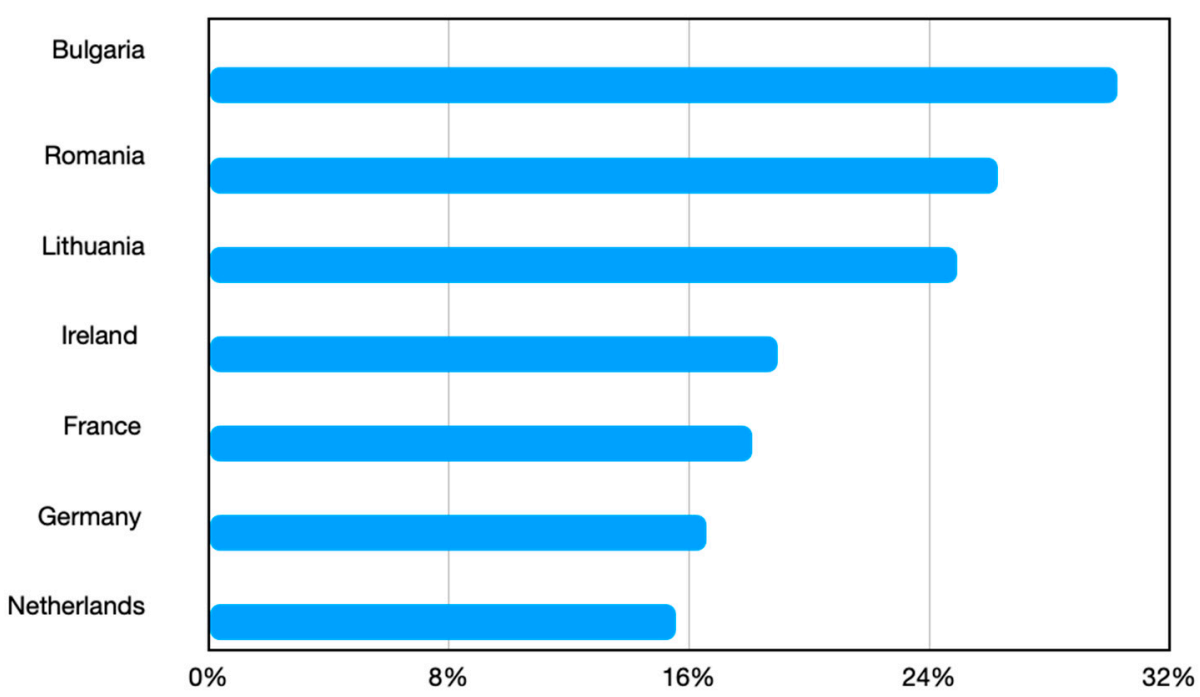

Figure 4. Percentage of women in tech in the EU. Source: Honeypot.com, accessed on 10 September 2021. 


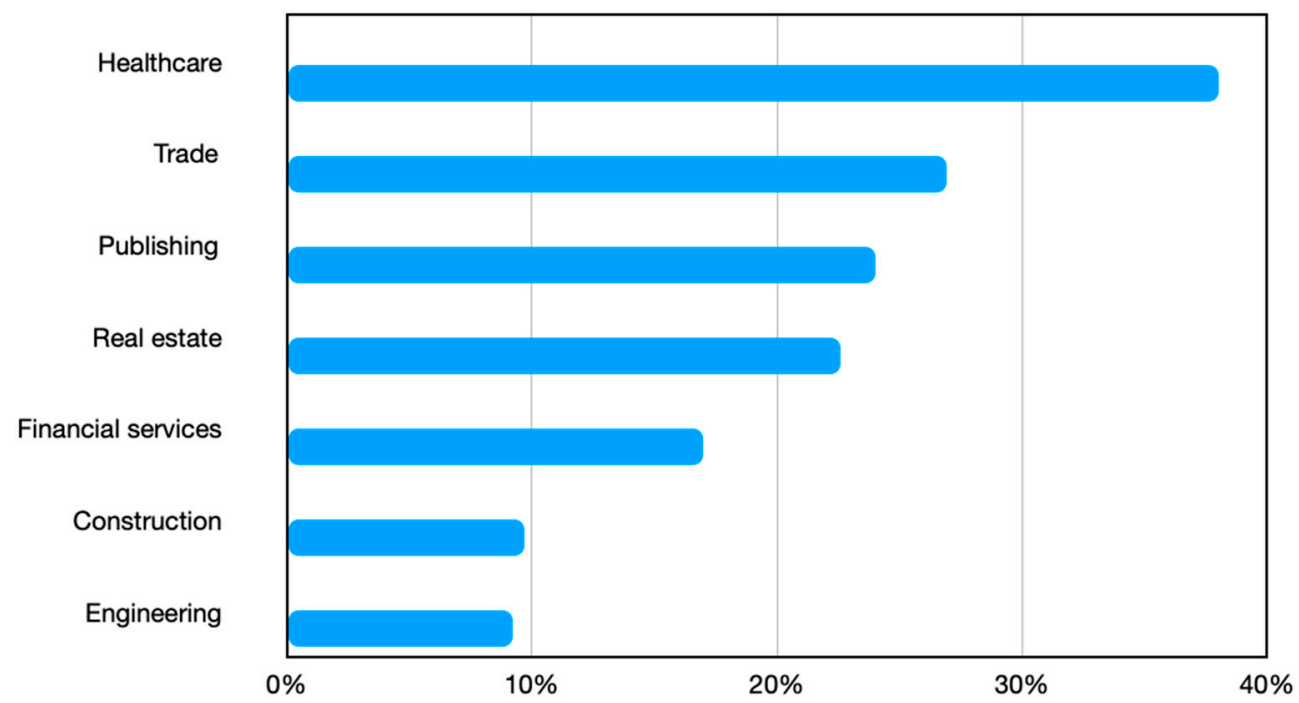

Figure 5. Percentage of women in leadership positions per industry in Germany. Source: statista.com, accessed on 10 September 2021.

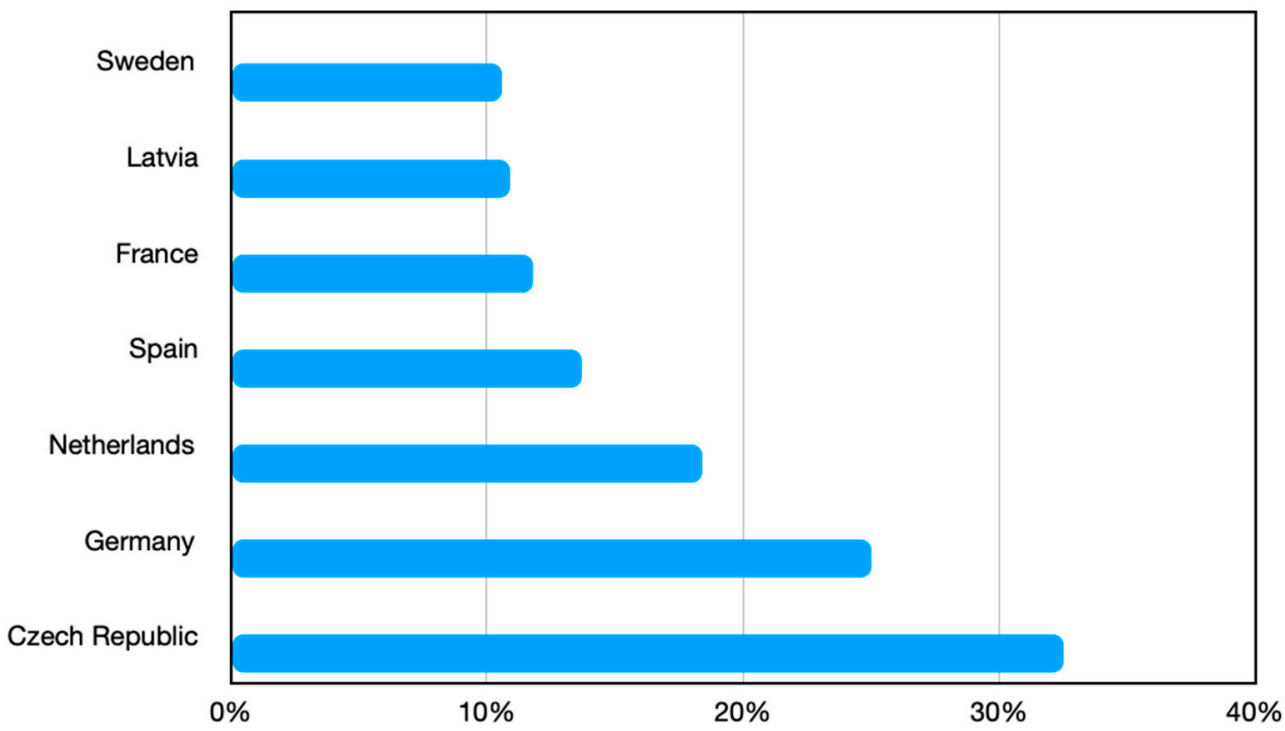

Figure 6. Gender pay gap in tech industry in the EU. Source: honeypot.com, accessed on 9 September 2021.

Not only are women outnumbered by their male co-workers in the tech industrythere are also very few female leaders in the tech industry (example from Germany), and the pay gap between men and women is significant.

However, more and more companies strive to become more diverse and inclusive and to bring on board more female employees and leaders. Apart from the ethical dimension, there are a couple of pragmatic reasons for doing so:

- Higher profit: A study among the Fortune 500 companies showed that with at least three female directors on the management board the following factors improved: the return on invested capital increased over $66 \%$, return on sales jumped over to $42 \%$, and return on equity went higher by $53 \%$ [43].

- Retention rate: According to Gallup's research, companies with more diverse staff have a $22 \%$ lower turnover rate compared to those with a more homogeneous one.

- Recruitment: Based on several studies in the recruitment industry, for ca. $67 \%$ of the job seekers diversity is a key point when choosing a future employer [44]. 
- Engagement and Performance: Research shows that gender-diverse groups are up to $87 \%$ more engaged compared to the homogenous teams [45].

- Demographic and Social change: Based on several studies, Generation Z, which is entering the workforce, puts high importance on values when it comes to choosing an employer, and diversity and equality play a predominant role [46].

- Diversity, including gender and cultural diversity of employees, and appropriate management of diversity are of great importance for the sustainable and innovative development of the organization [47].

Can current changes-accelerated digitalization and remote work model—help to bring more diversity to the companies? There has not been comprehensive research published yet on the topic, thus the authors will share exclusively findings from their observations within the examined company. Before the pandemic (March 2020) the company was hiring new employees only to have them work on-site from their Berlin office. Due to the introduced lockdown and imposed traveling restrictions, the company shifted its model and is currently hiring both onsite and remote employees. Since this change was introduced, there has been a significant influx of new female candidates and employees. Before March 2020, female workers composed 5\% of the entire workforce and none of them was part of the leadership group. As of now (August 2021) 20\% of all employees are female and two of them are part of the leadership circle. According to the quarterly engagement survey and interview feedback, hybrid or fully remote setup was one of the major factors to attract female employees. $85 \%$ of women from the examined organization claim that this was the convincing element for them to accept the job offer. Moreover, they state this model helps them navigate easier between professional and private obligations.

The examined organization decided to take steps forward and design its recruitment and HR process to expand gender diversity and inclusion. In terms of recruitment, the following actions were undertaken:

- Inclusive job descriptions: the company started using dedicated software (free to use) that helps to analyze the language of jobs descriptions and to make them more attractive to a diverse audience

- Diversity as a recruiting KPI: the organization set gender-diversity hires as a recruitment KPI, aiming for one "diversity" hire per month

- Boosting referral program: the recruitment team established a referral program (referral bonus scheme) and encourages your female employees to refer other female candidates

- Directed employer branding: diversity employees are given exposure on company's social media employer branding campaigns

- Diverse hiring committees: hiring committees are now designed in a way that they reflect as much as possible the diversity of the team.

As of general HR processes, the company puts its focus into the following actions:

- Female support group: a female empowerment group was created; they presented a concrete roadmap, initiatives to empower women and improve the skills of the female employees; it is as well a safe, experience-sharing space;

- Education: the whole company is being provided with training on gender bias, and the benefits of equal gender representation;

- Career path and performance reviews: to avoid equal career progression situation, where first to be chosen for promotion are the most represented employees, the company introduced an anonymous and gender-neutral software for their performance reviews;

- Community building: the company got engaged in female empowerment groups active in Berlin, but also remote ones;

- Flexibility and mental support: According to the McKinsey and LeanIn study, $41 \%$ of senior-level men reported feeling exhausted, compared to $54 \%$ of senior-level women during the COVID crisis [48] — considering this, the organization made sure they 
provide flexible working hours and mental support through cooperation with an

online therapist; they also provide employees with relaxation and ergonomy training.

Analyzing findings from the examined company, we can observe that digital changes caused by the pandemic not only increased the female quota but as well were a catalyst to improve and reform the organization so it is not only more diverse but most of all, more inclusive.

Diversity and inclusion as positive social elements are, alongside positive environmental factors, basic conditions to create a sustainable organization.

\section{Conclusions}

Certainly, the current epidemic crisis will lead to many changes, including with high probability, labor relations, and models, which were the center of the authors' attention [49-53]. It is still too early to surely state that the current pandemic combined with digitalization processes will pave the way to achieve sustainable development goals. Societies, economies, institutions, and organizations are being tested on whether they can embrace global thinking in terms of justice and responsibility [54-59].

Authors' study within a technology startup is a positive example of how to embrace digitalization and sudden changes to get a few steps closer to the sustainable company ideal. And creating a good, sustainable, "humanistic" organization is a milestone in paving the way to a fairer and more egalitarian society. Perhaps, we also need to consider the use of modern technologies to create a sustainable organization and a sustainable humanist society $[60,61]$. However, one should also remember the dangers of modern technologies [62]. In their research, the authors were testing the following hypothesis: The corona-caused digitalization of work and human resources processes helps organizations in achieving the ideal of sustainability. According to the gathered and analyzed primary data, it can be concluded that the stated hypothesis tends to be confirmed. The company, which was the main object of the research, reduced its $\mathrm{CO}_{2}$ emissions thanks to the introduction of:

- remote recruitment process

- remote and hybrid working models.

Additionally, the examined organization increased the number of female employees and female representatives in the leadership group, which makes the company more diverse and inclusive.

The authors of the article defined sustainability as a balance between economic, environmental, and social factors. Each aspect of the positive environmental change or positive social impact could not be measured in this research, that is why the authors focused their attention on the following factors:

- environment: $\mathrm{CO}_{2}$ emissions caused by business-related travel (recruitment), daily commute, usage of the office

- $\quad$ social aspects: improving diversity, equity and inclusion status thanks to recruiting more female employees and introducing policies to help to retain female workers.

There are, however, limitations to the conducted research. As mentioned, not all aspects of the environmental and social factors of sustainability could be taken into consideration. Moreover, the research was conducted within startups and scale-ups-neither big corporations nor other forms of businesses (for instance cooperatives) were examined. These, however, will be further directions of the authors' research.

The topic of digitalization and its influence on sustainability is of high significance for business. Not only does it show the direction of new processes and policies to the human resources managers but helps build a long-term strategy that takes into consideration social change, individuals' needs, and environmental aspects. In this sense, digitalization and modern technologies help create a sustainable organization and a sustainable humanist society $[60,61]$. 
Author Contributions: A.K., K.K., and Ł.R., writing-original draft preparation; A.K., K.K., and Ł.R., writing-review and editing; A.K., K.K., and Ł.R., writing-review and editing. All authors have read and agreed to the published version of the manuscript.

Funding: This research was funded by Department of Applied Social Sciences of the Faculty of Organization and Management of the Silesian University of Technology, grant number 2021: 13/020/BK21/0062.

Institutional Review Board Statement: Not applicable.

Informed Consent Statement: Not applicable.

Data Availability Statement: Not applicable.

Conflicts of Interest: The authors declare no conflict of interest.

\section{References}

1. Kuzior, A.; Kwilinski, A.; Tkachenko, V. Sustainable development of organizations based on the combinatorial model of artificial intelligence. Entrep. Sustain. Issues 2019, 7, 1353-1376. [CrossRef]

2. Kostera, M.; Glinka, B. Nowe Kierunki w Organizacji i Zarządzaniu. Organizacje, Konteksty, Procesy Zarządzania; Wolters Kluwer: Riverwoods, IL, USA, 2016.

3. Smith, A. Teoria Uczuć Moralnych; PWN: Warszawa, Poland, 1989.

4. Pfeffer, J. Seven practices of successful organizations. Calif. Manag. Rev. 1998, 40, 96-124. [CrossRef]

5. Koon, V.-Y. Bibliometric analyses on the emergence and present growth of humanistic management. Int. J. Ethics Syst. 2021, 37, 581-598. [CrossRef]

6. Kuzior, A. Aksjologia Zrównoważonego Rozwoju [Axiology of Sustainable Development]; Belianum: Banska Bystrica, Slovakia, 2014.

7. Aguiñaga, E.; Leal, A.R. Supply chain management, humanistic management, and circular economy: Fostering industry innovation and decent work through responsible consumption and production through partnerships. In Humanistic Management in Latin America; Routledge: Oxfordshire, UK, 2021; pp. 83-98. [CrossRef]

8. Benito Fraile, A.E.; Cárdenas Hinojosa, B.E. Corporate social responsibility based on dignity and well-being as keys to the humanistic management of human capital. In Humanistic Management in Latin America; Routledge: Oxfordshire, UK, 2021; pp. 38-49. [CrossRef]

9. Herrmann, B.; Rundshagen, V. Paradigm shift to implement SDG 2 (end hunger): A humanistic management lens on the education of future leaders. Int. J. Manag. Educ. 2020, 18, 100368. [CrossRef]

10. Armstrong, M. A Handbook of Human Resource Management Practice; Kogan Page Publishers: London, UK, 2006.

11. Armstrong, M.; Long, P. The Reality of Strategic HRM; IPM: London, UK, 1994.

12. Baird, L.; Meshoulam, I. Managing two fits of strategic human resource management. Acad. Manag. Rev. 1988, 13, 116-128. [CrossRef]

13. Becker, B.E.; Gerhart, S. The impact of human resource management on organizational performance: Progress and prospects. Acad. Manag. J. 1996, 39, 779-801.

14. Boxall, P.F.; Purcell, J. Strategy and Human Resource Management, Basingstoke, Palgrave Macmillan 2006. In European Perspectives of Human Resource Management; Brewster, C., Ed.; Routledge: Oxfordshire, UK, 2004; Volume 14, pp. 365-382.

15. Wright, P.M.; Snell, S.A.; Jacobsen, H.H. Current approaches to HR strategies: Inside-Out versus outside-in. Hum. Resour. Plan. 2004, 27, 36-46.

16. Armstrong, M. Armstrong's Handbook of Strategic Human Resource Management: Improve Business Performance through Strategic People Management; Kogan Page: London, UK, 2021.

17. Darvishmotevali, M.; Altinay, L. Green HRM, environmental awareness and green behaviors: The moderating role of servant leadership. Tour. Manag. 2022, 88, 104401. [CrossRef]

18. Giudici, E.; Dettori, A.; Caboni, F. Challenges of humanistic management education in the digital era. In Virtuous Cycles in Humanistic Management; Springer: Cham, Switzerland, 2020; pp. 21-35. [CrossRef]

19. Ramdani, L.; Boudinar, C. Human Resources Management in the era of Digital Transformation in Algeria: Challenges and Issues. In Proceedings of the 1st International Conference on Cyber Management and Engineering, CyMaEn, Hammamet, Tunisia, 26-28 May 2021; p. 9497296. [CrossRef]

20. Karwehl, L.J.; Kauffeld, S. Traditional and new ways in competence management: Application of HR analytics in competence management I [Traditionelle und neue Wege im Kompetenzmanagement: Anwendung von HR Analytics im Kompetenzmanagement]. Gr. Interakt. Organ. Z. Fur Angew. Organ. 2021, 52, 7-24. [CrossRef]

21. Mihova, T.; Ivanova, I. Industry 4.0-Challenge to human resources. Vide Tehnol. Resur.-Environ. Technol. Resour. 2021, 2, 112-115. [CrossRef]

22. Titor, S.E.; Opimpiev, A.Y.; Eriashvili, N.D. Legal Basis for the Electronic Document Workflow in HR Procedures. In Lecture Notes in Networks and System; Springer: Berlin/Heidelberg, Germany, 2021; Volume 155, pp. 1389-1396. [CrossRef] 
23. Da Costa Vieira Silva, L.S.; Kaczam, F.; de Barros Dantas, A.; Janguia, J.M. Startups: A systematic review of literature and future research directions. Rev. Ciências Adm. 2021, 23, 118-133. [CrossRef]

24. Cnbc.com. Available online: https://www.cnbc.com/2021/07/08/how-many-workers-will-be-returning-to-offices-and-howoften.html (accessed on 9 September 2021).

25. Colliers.com. Available online: https://www.colliers.com/en-pl/research/powrot-do-biura-szansa-i-wyzwanie (accessed on 9 September 2021).

26. Bloomberg.com. Available online: https://www.bloomberg.com/news/articles/2021-03-25/many-businesses-see-hybrid-workcontinuing-after-pandemic (accessed on 9 September 2021).

27. Kuzior, A.; Mańka-Szulik, M.; Krawczyk, D. Changes in the Management of Electronic Public Services in the Metropolis during the COVID-19 Pandemic. PJMS Pol. J. Manag. Stud. 2021, 4, 33-53.

28. Bekken, G. The Algorithmic Governance of Data driven-Processing Employment: Evidence-based Management Practices, Artificial Intelligence Recruiting Software, and Automated Hiring Decisions. Psychosociol. Issues Hum. Resour. Manag. 2019, 7, 25-30. [CrossRef]

29. Kassick, D. Workforce Analytics and Human Resource Metrics: Algorithmically Managed Workers, Tracking and Surveillance Technologies, and Wearable Biological Measuring Devices. Psychosociol. Issues Hum. Resour. Manag. 2019, 7, 55-60. [CrossRef]

30. Noack, B. Big Data Analytics in Human Resource Management: Automated Decision-Making Processes, Predictive Hiring Algorithms, and Cutting-Edge Workplace Surveillance Technologies. Psychosociol. Issues Hum. Resour. Manag. 2019, 7, 37-42. [CrossRef]

31. Nationalgeographic.com. Available online: https://www.nationalgeographic.com/science/article/coronavirus-causing-carbonemissions-to-fall-but-not-for-long (accessed on 9 September 2021).

32. Sekara, M.; Praveen Kumarb, T.R.; Selva Ganesh Kumarc, M.; Vaníčková, R.; Maroušek, J. Techno-Economic review on short-term anthropogenic emissions of air pollutants and particulate matter. Fuel 2021, 305, 121544. [CrossRef]

33. Ionescu, L. Leveraging Green Finance for Low-Carbon Energy, Sustainable Economic Development, and Climate Change Mitigation during the COVID-19 Pandemic. Rev. Contemp. Philos. 2021, 20, 175-186. [CrossRef]

34. Ionescu, L. Transitioning to a Low-Carbon Economy: Green Financial Behavior, Climate Change Mitigation, and Environmental Energy Sustainability. Geopolit. History Int. Relat. 2021, 13, 86-96. [CrossRef]

35. Globalworkplaceanalytics.com. Available online: https://globalworkplaceanalytics.com/whitepapers (accessed on 9 September 2021)

36. Time.com. Available online: https://time.com/5943530/covid-19-co2-emissions-climate-change (accessed on 9 September 2021).

37. Theccc.or.uk. Available online: https://www.theccc.org.uk/wp-content/uploads/2021/06/Progress-in-reducing-emissions2021-Report-to-Parliament.pdf (accessed on 9 September 2021).

38. Umweltbundesamt.de. Available online: https://www.umweltbundesamt.de/daten/klima/treibhausgas-emissionen-indeutschland\#nationale-und-europaische-klimaziele (accessed on 9 September 2021).

39. Güntner, A.V.; Endrejat, P.C.; Kauffeld, S. The Emergence of Employees' Change Readiness for Energy-Conservation Behavior during Guided Group Discussions. Front. Psychol. 2021, 12, 587529. [CrossRef] [PubMed]

40. Chu, J.; Liu, H.; Salvo, A. Air pollution as a determinant of food delivery and related plastic waste. Nat. Hum. Behav. 2021, 5, 212-220. [CrossRef] [PubMed]

41. Acosta.com. Available online: https://www.acosta.com/news/new-acosta-report-details-how-COVID-19-is-reinventing-howamerica-eats (accessed on 9 September 2021).

42. Preprints.org. Available online: https://www.preprints.org/manuscript/202101.0153/v2 (accessed on 9 September 2021).

43. Fortune.com. Available online: https:/ / fortune.com/2016/02/08/women-leadership-profits/ (accessed on 11 September 2021).

44. Gallup.com. Available online: https://www.gallup.com/workplace/236543/business-benefits-gender-diversity.aspx (accessed on 15 September 2021).

45. Hbr.org. Available online: https://hbr.org/2016/11/why-diverse-teams-are-smarter (accessed on 15 September 2021).

46. Deloitte.com. Available online: https://www2.deloitte.com/content/dam/Deloitte/us/Documents/consumer-business/welcometo-gen-z.pdf (accessed on 15 September 2021).

47. Grebski, M. Mobility of the Workforce and Its Influence on Innovativeness (Comparative Analysis of the United States and Poland). Prod. Eng. Arch. 2021, 27, 272-276. [CrossRef]

48. Mckinsey.com. Available online: https://www.mckinsey.com/featured-insights/diversity-and-inclusion/women-in-the-workplace (accessed on 15 September 2021).

49. Kuzmenko, O.V.; Kashcha, M.O.; Shvindina, H.O.; Hakimova, Y.; Tagiyeva, N.; Shyian, O. Healthcare financing and budgeting: The regional policy priorities in response to COVID-19. Financ. Credit. Act. Probl. Theory Pract. 2021, 2, 310-324.

50. Kuzior, A.; Mańka-Szulik, M.; Marszałek-Kotzur, I. The impact of the COVID-19 pandemic on the economic and psychological condition of individuals and societies. In Proceedings of the 37th International Business Information Management Association Conference (IBIMA), Cordoba, Spain, 1-2 April 2021; Khalid, S.S., Ed.; International Business Information Management Association: Cordoba, Spain, 2021.

51. Lyulyov, O.; Us, Y.; Pimonenko, T.; Kwilinski, A.; Vasylieva, T.; Dalevska, N.; Polcyn, J.; Boiko, V. The Link between Economic Growth and Tourism: COVID-19 Impact. In Proceedings of the 36th International Business Information Management Association (IBIMA), Granada, Spain, 4-5 November 2020; pp. 8070-8086. 
52. Mańka-Szulik, M.; Krawczyk, D. The activities of a local government entity during pandemic conditions using Zabrze as an example. Sil. Univ. Technol. Sci. Pap. Organ. Manag. 2020, 148, 401-415. [CrossRef]

53. McKibbin, W.; Fernando, R. The economic impact of COVID-19. In Economics in the Time of COVID-19; Baldwin, R., di Weder Mauro, B., Eds.; Centre for Economic Policy Research: London, UK, 2020; pp. 45-51.

54. Ciążela, H. Problemy i Dylematy Etyki Odpowiedzialności Globalnej; Wydawnictwo Akademii Pedagogiki Specjalnej im. Marii Grzegorzewskiej: Warszawa, Poland, 2006.

55. Zozul'ak, J.; Zozul'aková, V. Corporate social responsibility-modern challenge or inevitability. Zesz. Naukowe Organ. I Zarzadzanie 2015, 84, 247-259.

56. Kuzior, A. Polskie i niemieckie doświadczenia w projektowaniu i wdrażaniu zrównoważonego rozwoju. [Polish and German Experiences in Planning and Implementation of Sustainable Development]. Probl. Ekorozw. 2010, 5, 81-89.

57. Harari, Y.N. The world after coronavirus. Financ. Times 2020, 20, 2020.

58. Rab, Ł.; Kettler, K. Perspective of sustainable development in post-pandemic world: Surveillance capitalism and hopes. Soc. Regist. 2020, 4, 159-166. [CrossRef]

59. Rąb, Ł. Contemporary faces of capitalism: From homo oeconomicus to homo ecologicus. Zesz. Naukowe Organ. I Zarządzanie 2019, 140, 285-292. [CrossRef]

60. Kuzior, A.; Lobanova, A. Tools of information and communication technologies in ecological marketing under conditions of sustainable development in industrial regions (through examples of Poland and Ukraine). J. Risk Financ. Manag. 2020, 13, 238. [CrossRef]

61. Kwilinski, A.; Tkachenko, V.; Kuzior, A. Transparent cognitive technologies to ensure sustainable society development. J. Secur. Sustain. Issues 2019, 9, 561-570. [CrossRef]

62. Dzhalladova, I.; Škapa, S.; Novotná, V.; Babynyuk, A. Design and Analysis of a Model for Detection of Information Attacks in Computer Networks. Economic computation and economic cybernetics studies and research. Acad. Econ. Stud. 2019, 53, 95-112. [CrossRef] 